\title{
Strengthening diversity in nursing: The practices and preparedness of nursing faculty
}

\author{
Kenya V. Beard \\ School of Nursing, Hunter College, New York, United States \\ Correspondence: Kenya V. Beard. Address: School of Nursing, Hunter College, New York, United States. \\ Email: kbeard@hunter.cuny.edu
}

Received: May 31, 2014

Accepted: August 24, 2014

Online Published: September 9, 2014

DOI : 10.5430/jnep.v4n11p59

URL: http://dx.doi.org/10.5430/jnep.v4n11p59

\begin{abstract}
Objective: Faculty who are aware of culturally responsive practices are better positioned to implement teaching-learning strategies that meet the educational needs of culturally diverse learners. This study investigated the extent to which faculty used practices that promoted the academic success of African American and Hispanic minority nursing students and their preparedness in teaching these groups.
\end{abstract}

Methods: The Nurse Educator Cultural Competency Survey was used to measure the cultural competence of 34 nurse educators in the domains of practices used in teaching under-represented minorities and preparedness to teach these groups. Data was analyzed using a descriptive design.

Results: Findings revealed that not all faculty members felt adequately prepared to teach minorities or adopt practices that promoted their academic success.

Conclusions: The underrepresentation of minority nurses may continue unless more research that examines the capacity of nursing programs to prepare all educators to create culturally responsive learning environments is undertaken.

\section{Key words}

Diversity, Cultural competence, Preparedness, Teaching practices

\section{I ntroduction}

The continued underrepresentation of African American, Hispanic/Latino and American Indian nurses threatens initiatives to end racial and ethnic health disparities. Although the Sullivan Commission ${ }^{[1]}$ reported that "the lack of minority health professionals is compounding the nation's persistent racial and ethnic health disparities” close to a decade ago, and significant resources have been allocated to increase minority representation in nursing, few gains have been made. In 2008, the collective percentage of African Americans (5.4\%), Hispanic/Latino (3.6\%) and American Indians (0.3\%) in nursing rose slightly from $6.8 \%$ in 2004 to $9.3 \%{ }^{[2]}$. Whereas this $2.5 \%$ gain shows promise, concerted efforts have failed to produce a workforce that mirrors the ethnic composition of the United States. What's more, the ethnic representation of minority groups is expected to rise from $29.7 \%$ today to over $50 \%$ by $2050^{[3]}$. More must be done to strengthen diversity in nursing ${ }^{[4-6]}$. 
Diversity is defined as "affirming the uniqueness of and differences among persons, ideas, values and ethnicities" (p.1) ${ }^{[7]}$. It is believed that diversity will lead to better patient/provider communication, improve the treatment of diverse groups and strengthen the delivery of culturally relevant care ${ }^{[8]}$. The U.S. Department of Health and Human Services report, A Nation Free of Heath Disparities echoed prior reports and stated that diversity is key to patient centered care and an integral component of decreasing healthcare disparities ${ }^{[5]}$. However, as our society becomes more pluralistic, the ability to end health disparities could extend beyond our reach unless new approaches to increasing diversity in nursing and other health professions are explored.

It has been recommended that schools adopt reform measures that strengthen workforce diversity and remove barriers to graduating a diverse group of students ${ }^{[9]}$. One significant obstacle is the attrition rates of under-represented minority students. In some schools, they have the highest attrition rate and poor academic performance is a contributing factor ${ }^{[10,11]}$. The academic failure and higher attrition rates for underrepresented students could stem from learning needs not being met ${ }^{[10]}$.

Faculty who are prepared to create learning environments that meet the educational needs of underrepresented groups could help strengthen diversity in nursing. However, some teachers do not feel adequately prepared to teach content related to cultural competence ${ }^{[12]}$ and some lack confidence in their abilities to adapt classroom processes in a way that promotes the academic success of minority students ${ }^{[13]}$. Even still, some educators do not consider race and ethnicity a factor when teaching diverse groups of students ${ }^{[13,14]}$. To that end, the preparedness of nurse educators and the practices they use to deliver culturally responsive teaching in today's pluralistic society should be examined.

\section{Review of the literature}

As society grows in diversity, nursing classrooms are likely to become more ethnically and racially mixed, which could result in a cultural chasm. A gap between cultures exists when the institution's culture differs significantly from that of the student's. This challenges the teacher's ability to deliver culturally relevant instruction.

It is widely accepted that cultural competence plays a significant role in improving patient outcomes and is incorporated into the role of nurses as providers of patient-centered care ${ }^{[15]}$. In nursing education, the literature has typically focused on the importance of cultural competence as it relates to patient outcomes and not student outcomes ${ }^{[16-18]}$. Dudas examined the literature surrounding cultural competence in nursing and nursing education ${ }^{[19]}$. The author identified several expected consequences of cultural competence which included enhanced patient-provider communication, improved patient satisfaction and a decrease in malpractice claims.

In nursing, cultural competence is not always viewed as a way to improve learning outcomes for underrepresented nursing students. However, Pacquiao reported that faculty should receive training in cultural competency to strengthen diversity in nursing ${ }^{[20]}$. Bednarz, Schim and Doorenbos shared that cultural competence strengthens the effectiveness of educators who teach diverse students ${ }^{[21]}$. In teacher education, the cultural competence of educators is an essential quality and is viewed as an integral part in closing academic achievement gaps ${ }^{[22]}$.

Numerous definitions have been used to describe cultural competence, yet none were identified by this author that operationalizes cultural competence in relation to the role of nurse educator. Thus, Davis' definition of cultural competence for teacher education was modified for nursing education and used as a model to guide this study ${ }^{[23]}$. Cultural competence is the ability of nurse educators to transform their knowledge about individuals and groups of learners into specific standards, attitudes, practices and policies that empower them to effectively meet the educational needs of today's culturally diverse learner and improve academic outcomes.

In teacher education it is expected that educators “...become knowledgeable about their students' distinctive cultural backgrounds so they can translate that knowledge into effective instruction and enriched curriculum” (p. 2) ${ }^{[22]}$. In nursing, 
it is recommended that educators receive training in the science of teaching and learning ${ }^{[15,25]}$, which includes the recognition of multicultural influences on teaching and learning ${ }^{[26]}$. However, since nurse educators are not required to receive formal training in teaching culturally diverse students, this recognition is sometimes lacking.

While it is often assumed that being a nurse gives one the inherent ability to teach nursing, the National League for Nursing recognized that greater emphasis is needed in the teaching/pedagogy component of the nurse educator's role ${ }^{[27]}$. It has been reported that "faculty and administrators of graduate nursing programs have focused their attention on developing robust nursing research, ignoring the need to prepare new faculty to address the specific educational demands of teaching the complex practice of nursing” (p. 26) ${ }^{[28]}$. While cultural competence is widely supported as an integral part of nursing curriculum, not all nursing faculty are comfortable teaching content that involves cultural competence ${ }^{[12]}$. Nurse educators who are not prepared to teach in a way that's culturally responsive could hinder the academic success of underrepresented nursing students and stall efforts to increase their presence in nursing. Hence, how nursing programs prepare future educators to meet the educational needs of all students deserves further inquiry.

The American Association of Colleges of Nursing (AACN) in their Preferred Vision of the Professoriate in Baccalaureate and Graduate Nursing Programs recommended that doctoral prepared nursing faculty have preparation in educational methods and pedagogies if they are assuming an academic role ${ }^{[15]}$. They also recommended that, at a minimum, nurse educators have graduate-level academic preparation along with advanced expertise in the content they teach. They added that clinical instructors should have clinically focused graduate preparation. While these recommendations promote clinical expertise, the extent to which they ensure the preparedness of nurse educators to teach in today's multicultural classrooms and facilitate the success of minority students has yet to be examined.

Faculty who are unprepared to teach in diverse settings could hinder the academic success of minority students. While this statement is generally accepted, there is a dearth of studies that examine the relationship between the cultural competence of faculty and academic success of minority nursing students. However, Ume-Nwagbo used the cultural diversity questionnaire to examine the cultural competence of nurse educators from nine different colleges ${ }^{[29]}$. The author found a relationship between cultural competence scores of faculty and the graduation rates of minority nursing student. This study supports the significance of cultural competence in relation to the academic success of minority students.

There are numerous practices performed by nurse educators that have been shown to improve the academic success of minority students. For example, since some groups refrain from asking questions because they perceive it as a sign of disrespect, faculty should encourage students to ask questions ${ }^{[30]}$. Brown and Marshall studied enrollment and success tactics at a historically black university ${ }^{[11]}$. They reported a $25 \%$ increase in student retention after implementing a Baccalaureate Enrollment and Success Tactics for RNs project that utilized integrative teaching and learning strategies, test taking strategies, and mentoring. Faculty who provided frequent interactions with students who faced academic difficulty and did not just send them to outside resources, showed that they cared about the student's success ${ }^{[11,31]}$. This paper examines the views of faculty regarding practices used and their preparedness in teaching Black/African American and Hispanic/Latino nursing students. These two ethnic groups were singled out in this study due to their significant under-representation in nursing and their representation in the urban population where this study took place. Specifically, the study posed the following research questions:

1) Do nurse educators feel adequately prepared to educate African American and Hispanic/Latino nursing students?

2) Do nurse educators use evidenced based practices that promote the retention and graduation of African American and Hispanic nursing students? 


\section{Methods}

\subsection{Design}

To evaluate the practices used by nurse faculty and their preparedness in educating underrepresented nursing students, an exploratory descriptive design was used. This study took place at an ethnically and racially diverse urban institution in the northeastern region of the United States. Institutional Review Board approval was obtained prior to the start of this study.

\subsection{I nstrument}

The Nurse Educator Cultural Competency Survey was designed by the principle investigator to measure the cultural competence of nurse educators in the domains of practices used in teaching under-represented minorities and preparedness to teach these groups. Face validity was established by the subjective judgment of three expert reviewers and revisions were made. The original survey consisted of 20 Likert-type questions that were divided into 3 subscales; role, practices and preparedness. Responses ranged from (1) Strongly Disagree to (5) Strongly Agree. After performing scale reliabilities only 9 Likert-type items were retained and two subscales (practices and preparedness) remained. Questions 1 to 8 were demographic questions that identified age, gender, ethnicity, English as first language, classroom diversity and teaching traits (years of teaching and program level) and students. Questions 9-17 were divided into two subscales: practices used (5 questions) and preparedness (4 questions) in educating underrepresented nursing students.

\subsection{Participants and recruitment}

A convenience sample of nurse educators who taught nursing courses at an urban institution was used. Participants were recruited by email and the survey was open to both adjunct and full time faculty. Those who agreed to participate used a hyperlink to redirect them to the online survey. A second email was sent to faculty two weeks after the initial email to increase the response rate. The purpose of the study, along with instructions on how to complete the survey was included with the survey questions. In addition, participants were instructed that the ethnically and racially diverse nursing students referred specifically to African American and Hispanic students. Completion and submission of the survey implied consent. Anonymity of each participant was maintained.

\subsection{Data analysis}

Data were analyzed using the Statistical Package for the Social Sciences (SPSS) version 20 software program. Faculty responses to the survey were analyzed using descriptive statistics.

\section{Results}

Thirty-four nurse educators who taught in the nursing program agreed to participate in this study. However, two participants skipped a few questions on the survey. The response rate was $43.8 \%$. The majority of the educators were females $(77.1 \%, n=27)$ over the age of $48(91.4 \%, n=32)$. The racial background of the respondents was as follows: Caucasian 82.9\% ( $(=29)$, African American 8.6\% ( $(n=3)$, Hispanic 2.9\% $(n=1)$ and other 5.7\% ( $=2)$. English was the first language for $88.6 \%(\mathrm{n}=31)$ of the participants. While it appears that the diversity among the respondents closely parallels the AACN's (2011) report which identified 12.6\% of nursing faculty in their member schools as minorities, it must be noted that this survey didn't distinguish between adjunct and full-time faculty. The majority of educators (87.1\%, $\mathrm{n}=27)$ taught for more than six years and held a doctoral degree $(65.7 \% \mathrm{n}=23)$. All the educators reported that their student population was diverse and included African American or Hispanic students.

\subsection{Preparedness}

Reliability analysis for the four survey items that examined preparedness was determined using Cronbach's Alpha. The value for coefficient alpha was .821. Descriptive statistics were used to analyze faculty preparedness in educating minority 
nursing students. The total minimum score was 1.00 and the maximum was 4.5 . The mean was 2.9 with a standard deviation of 1.0. This indicates that the educators tended to remain neutral in regards to feeling prepared to educate African American and Hispanic students.

Examining each item revealed that few educators agreed that they took a college course that addressed educating ethnically and racially diverse nursing students $(27.3 \%, \mathrm{n}=9)$. In addition, less than half attended staff development activities related to this subject $(42.4 \%, \mathrm{n}=14)$ or felt prepared to teach this population based on the inservices they attended $(48.5 \%, n=16)$. Conversely, over half of the educators $(53.1 \%, n=17)$ reported that college courses helped them feel prepared to teach ethnically and racially diverse students.

\subsection{Practices}

Five survey items examined the practices educators used to teach African American and Hispanic students. Reliability analysis for these five items showed a coefficient alpha of .751. The total minimum score was 2.4 and the maximum score was 4.8. The mean score was 3.5 and the standard deviation was .6. This revealed that the educators tended to use practices that promoted the academic success of minority students.

When African American and Hispanic students faced academic difficulty, the majority of educators requested meetings (55.9\%, $n=19)$, encouraged students to ask questions $(79.4 \%, n=27)$, or referred them to outside resources $(69.7 \%, n=$ 23). However, less than half developed corrective action plans $(44.1 \%, n=15)$ and even fewer provided weekly interactions $(17.6 \%, \mathrm{n}=6)$. Although time constraints may limit faculty availability, it is imperative that faculty adopt practices that promote the retention of students.

\section{Discussion}

For decades the nursing profession has strived to increase racial and ethnic diversity. Educators who possess cultural competence are better positioned to communicate effectively with culturally diverse students, meet their learning needs and promote their academic success ${ }^{[29,32]}$. Conversely, when educators are not prepared to teach ethnically and racially diverse nursing students they could contribute to the minority student's academic failure. This is not to imply that cultural competence has an endpoint and should be mastered. Rather, it is a process that one continuously strives for yet never truly reaches in its entirety ${ }^{[33]}$. Since competence denotes an outcome, cultural humility has been used by some authors to emphasize that the approach to cultural competence requires a life-long commitment and continuous self-reflection ${ }^{[34,35]}$.

The data from the survey used in this pilot study revealed that not all nursing faculty felt adequately prepared to teach African American and Hispanic nursing students or were trained to do so. Few reported ever taking a college course that addressed teaching these two groups. Yet those who took college courses in general believed that the courses did prepare them to educate ethnically and racially diverse nursing students. This study corroborates a prior study by Starr, Shattell, and Gonzales which also found that not all educators felt well versed in the area of cultural competence ${ }^{[12]}$. Nursing schools that seek to improve the academic success of minority students should examine the extent to which nurse educators' feel prepared to teach in today's multicultural classroom and the effect their preparedness has on learning outcomes. In addition, how educators are prepared to teach in today's pluralistic society and whether the nursing profession needs to strengthen educational standards that include multicultural competencies to teach nursing should be further explored.

While the educators tended to use evidence based practices that promoted the academic success of underrepresented students, some educators did not. Responses revealed that not all faculty provided corrective action plans or weekly interactions with these students. Faculty availability, advisement ${ }^{[11]}$ and frequent interactions ${ }^{[31]}$ are key tactics that promote the academic success of minority students. Corrective action plans allow students to work with faculty to identify problems and develop strategies to promote their academic success. However, these tactics may be difficult to employ in 
institutions that have high student:faculty ratios or large classrooms. Institutions should provide faculty with resources to meet the educational needs of diverse student populations. Tinto reported that student retention requires the commitment of faculty to provide frequent interactions and the absence of interaction leads to isolation and "almost always enhances the likelihood of departure" (p. 117) ${ }^{[36]}$. Faculty should not have to bear the responsibility of meeting the learning needs of ethnically and racially diverse students alone ${ }^{[20]}$.

More must be done to emphasize the importance of cultural competence and its effect on academic outcomes. How cultural differences impact learning and which practices promote academic success deserve greater emphasis. It has been recommended that faculty receive training in multicultural instruction ${ }^{[13]}$.

Nursing schools that seek to increase graduation rates for underrepresented minorities may find it challenging to do so if educators have not been trained, don't feel adequately prepared, or are unaware of practices that promote the academic success of minority nursing students. Thus, the underrepresentation of minority nurses may continue unless more research that examines the attitudes of faculty regarding their role in educating minority students and capacity of nursing programs to prepare educators to teach in ethnically and racially diverse students is undertaken. Findings should help generate a discourse that seeks to strengthen our educational systems ability to prepare nurse educators to teach in a manner that's culturally responsive. In addition, findings should prompt institutions to explore whether the educational needs of nursing faculty in teaching underrepresented populations are being met.

\section{Limitations}

There are several limitations to this study. First, this pilot study relied on a low response rate and a small convenience sample of thirty-five nurse educators which limits generalizations of the findings. It is possible that the responses made by those who took part in the survey may not reflect the practices and preparedness of all nursing faculty at this institution. Secondly, the author of this paper and the participants taught at the same institution and the survey posed personal and socially sensitive questions. Although anonymity was provided, the author was a colleague and faculty could have felt compelled to respond in a way that they felt was socially acceptable. Thus, social desirability could be an additional limitation of this study in spite of the fact that the survey was self-administered. Lastly, this study examined whether practices were used and does not attempt to identify why faculty do or do not use the identified practices. It should be noted that there are multiple variables that influence the adoption of educational practices such as time constraints and awareness which were not examined. Future studies that seek to strengthen the Nurse Educator Competency Survey should consider these additional variables.

\section{References}

[1] Sullivan Commission. Missing persons: Minorities in the health profession [Internet]. c2004. Available from: http://www.aacn.nche.edu/Media/pdf/SullivanReport.pdf.

[2] Bureau of Health Professions. The registered nurse population; Findings from the 2008 national sample survey of registered nurses. c2010. Available from: http://bhpr.hrsa.gov/healthworkforce/rnsurveys/rnsurveyfinal.pdf.

[3] Humes K, Jones N A, Ramirez R R. Overview of race and Hispanic origin: 2010. 2010 Census Briefs. 2011. Available from: http://www.census.gov/prod/cen2010/briefs/c2010br-02.pdf.

[4] Institute of Medicine. The future of nursing: Leading change, advancing health. c2011. Available from: http://wwww.nap.edu/catalog.php?record_id=12956

[5] U.S. Department of Health and Human Services. HHS action plan to reduce racial and ethnic health disparities: A nation free of heath disparities. c2011. Available from: http://minorityhealth.hhs.gov/npa/files/Plans/HHS/HHS_Plan_complete.pdf

[6] Robert Wood Johnson Foundation. Nurse Leaders, IOM report call for push to increase diversity in nursing. c2011. Available from: http://www.rwjf.org/newsroom/product.jsp?id=71931

[7] National League for Nursing. About the NLN. c2006. Available from: www.nln.org/aboutnln/corevalues.htm

[8] Institute of Medicine. In the nations compelling interest: ensuring diversity in the health-care workforce. c2004. Available from: http://www.iom.edu/CMS/3740/4888/18287.aspx.

[9] American Association of Colleges of Nursing. Fact sheet: Enhancing diversity in the nursing workforce. c2011. Available from: http://www.aacn.nche.edu/mediarelations/diversityFS.pdf 
[10] Giddens J. Achieving diversity in nursing through multicontextual learning environments. Nursing Outlook. 2008; 56(2):78-83. PMid:18374802 http://dx.doi.org/10.1016/j.outlook.2007.11.003

[11] Brown J, Marshall BL. A historically black university's baccalaureate enrolment and success tactics for registered nurses. J of Professional Nursing. 2008; 24(1): 21-29. PMid:18206839 http://dx.doi.org/10.1016/j.profnurs.2007.06.006

[12] Starr S, Shattell, MM, Gonzales C. Do nurse educators feel competent to teach cultural competency concepts? Teaching and Learning in Nursing. 2011; 6(2): 84-88. http://dx.doi.org/10.1016/j.teln.2010.12.004

[13] Beard K. Teaching in a multicultural society: how nurse educators describe their role. J of the National Black Nurses Association. 2013; 24(2): 64-71.

[14] Sleeter CE, Grant CA. Making choices for multicultural education: Five approaches to race, class, and gender (6th ed.). New Jersey: John Wiley \& Sons; 2009.

[15] American Association of Colleges of Nursing. The preferred vision of the professoriate in baccalaureate and graduate nursing programs. c2008 Available from: http://www.aacn.nche.edu/publications/position/PreferredVision.pdf

[16] Bauman SL. Beyond cultural competence: nursing practice with political refugees. Nursing Science Quarterly. 2009; 22(83): 83-84. PMid:19176864 http://dx.doi.org/10.1177/0894318408329153

[17] Fulbright-Sumpter D, Brooks-Carthon JM. Competence in undergraduate and graduate nursing curricula. J of Professional Nursing. 2011; 27(1): 43-49. PMid:21272835 http://dx.doi.org/10.1016/j.profnurs.2010.09.005

[18] Baernholdt M, Drake E, Maron, F, Neymark K. Fostering internationalization: an American-Danish semester-long undergraduate nursing student exchange program. International Nursing Review. 2013; 60(20): 221-227. PMid:23692006 http://dx.doi.org/10.1111/inr.12005

[19] Dudas KI. Cultural competence: an evolutionary concept analysis. Nursing Education Perspectives. 2012 ; $33(5)$ : $317-321$. PMid:23061190 http://dx.doi.org/10.5480/1536-5026-33.5.317

[20] Pacquiao D. The relationship between cultural competence education and increasing diversity in nursing schools and practice settings. J of Transcultural Nursing. 2007; 18(28):28-37. PMid:17204813 http://dx.doi.org/10.1177/1043659606295679

[21] Bednarz H, Schim S, Doorenbos A. Cultural diversity in nursing education: perils, pitfalls, and pearls. J of Nursing Education. 2010; 49(5):253-260. PMid:20143759 http://dx.doi.org/10.3928/01484834-20100115-02

[22] National Education Association. Promoting educators' cultural competence to better serve culturally diverse students. c2008. Available from: w.nea.org/assets/docs/PB13_CulturalCompetence08.pdf.

[23] Davis K. Exploring the intersection between cultural competency and managed behavioral health care policy: implications for state and county mental health agencies [Internet]. Alexandria (VA): National Technical Assistance Center for State Mental Health Planning; c1997. Available from: http://www.nasponline.org/resources/culturalcompetence/definingcultcomp.aspx.

[24] National Council of State Boards of Nursing: nursing faculty qualifications and roles [Internet]. c2008. Available from: https://www.ncsbn.org/Final_08_Faculty_Qual_Report.pdf.

[25] National League for Nursing: position statement: the preparation of nurse educators [Internet]. c2002. Available from: http://www.nln.org/aboutnln/PositionStatements/preparation051802.pdf.

[26] National League for Nursing: core competencies of nurse educators with task statements [Internet]. c2005. Available from: http://www.nln.org/facultyprograms/pdf/corecompetencies.pdf.

[27] National League for Nursing: priorities for research in nursing education [Internet]. c2003. Available from: http://www.nln.org/aboutnln/RFP/priorities.pdf.

[28] Benner P, Sutphen M, Leonard V, Day L. Educating nurses: A call for radical transformation. San Francisco: Jossey-Bass; 2009.

[29] Ume-Nwagbo PN. Implications of nursing faculties’ cultural competence. J of Nursing Education [Internet]. 2012; 51(5): 262-268. PMid:22432533 http://dx.doi.org/10.3928/01484834-20120323-01

[30] Brown J. Developing an English-as-a-second-language program for foreign-born nursing students at an historically black university in the United States. J of Transcultural Nursing [Internet]. 2008 [cited 2013 Feb 10]; 19(2): 184-191.

[31] Wong ST, Seago JA, Deane D, Grumbach K. College students' perceptions of their experiences: what do minority students think? J of Nursing Education [Internet]. 2008; 47(4): 190-195. http://dx.doi.org/10.3928/01484834-20080401-10

[32] Banks J, Banks C. An introduction to multicultural education (4th ed.). Boston: Pearson Education; 2008.

[33] Camphina-Bacote J. The process of cultural competence in the delivery of health care services: a model of care. J of Transcultural Nursing [Internet]. 2002; 13(3): 181-184. http://dx.doi.org/10.1177/10459602013003003

[34] Tervalon M, Murray-Garcia J. Cultural humility versus cultural competence: a critical distinction in defining physician training outcomes in multicultural education. J of Health Care For the Poor and Underserved [Internet]. 1998; 9(2): 117-125. PMid:10073197 http://dx.doi.org/10.1353/hpu.2010.0233

[35] Schim SM, Doorenbos A, Benkert R, Miller J. Culturally congruent care: putting the puzzle together. J of Transcultural Nursing [Internet]. 2007; 18(2): 103-110. PMid:17416711 http://dx.doi.org/10.1177/1043659606298613

[36] Tinto, V. Leaving college: Rethinking the causes and cures of student attrition. Chicago: University of Chicago Press; 1987. 